ARTICLE

\title{
Analytical model of the pedagogy of the oppressed: systematization of the Paulo Freire's Method
}

Ramon Rodrigues Ramalho

\section{ABSTRACT}

This article describes the characteristic elements of the pedagogy of the oppressed, highlighting the key pedagogical mediations involved in the so-called Paulo Freire's Method, which is systematized as an Analytical Model at the end of the text. To do so, we have focused on the socio-pedagogical experiences developed by social movements, understanding them as strategies offormation. This study is the result of more than fifteen years of academic investigation along with social movements from Brazil and Argentina. From this perspective, we conducted a bibliographic review of Freire's major work, Pedagogy of the oppressed, herein described in two parts: the Complex of the Oppressed and the Dialogical Circuit, as a synthetic reading offered of Freire's pedagogical proposal. Our objective is to develop a more comprehensive knowledge about these formation processes, promoting the educational experiences of the social movements, and spread Paulo Freire's thinking.

\section{KEYWORDS}

Paulo Freire; Pedagogy of the oppressed; social movements; Dialogical Circuit; generative themes; cultural invasion.

'Universidad de Buenos Aires, Buenos Aires, Argentina. 


\section{MODELO ANALÍTICO DA PEDAGOGIA DO OPRIMIDO: SISTEMATIZAÇÃO DO MÉTODO PAULO FREIRE}

RESUMO

Este artigo descreve os elementos característicos da pedagogia do oprimido, destacando as mediações pedagógicas centrais envolvidas no chamado método de Paulo Freire, que é sistematizado como um modelo analítico no final do texto. Para tal, centramo-nos nas experiências sociopedagógicas desenvolvidas pelos movimentos sociais, entendendo-as como estratégias de formação. $\mathrm{O}$ estudo aqui apresentado é o resultado de mais de quinze anos de investigação acadêmica, com movimentos sociais do Brasil e da Argentina. Nessa perspectiva, realizamos uma revisão bibliográfica da obra central de Freire, Pedagogia do oprimido, aqui apresentada em duas partes: o complexo do oprimido e o circuito dialógico, como leitura sintética que oferecemos da proposta pedagógica de Freire. O objetivo é desenvolver um conhecimento mais abrangente sobre esses processos de formação, promover as experiências educativas dos movimentos sociais e difundir o pensamento de Paulo Freire.

\section{PALAVRAS-CHAVE}

Paulo Freire; pedagogia do oprimido; movimentos sociais; circuito dialógico; temas geradores; invasão cultural.

\section{MODELO ANALÍTICO DE LA PEDAGOGÍA DEL OPRIMIDO: SISTEMATIZACIÓN DEL MÉTODO PAULO FREIRE}

\section{RESUMEN}

Este artículo describe los elementos característicos de la Pedagogía del Oprimido, resaltando las mediaciones pedagógicas centrales involucradas en el llamado Método Paulo Freire, sistematizado como un Modelo Analítico al final del texto. Para ello, nos enfocamos en las experiencias sociopedagógicas desarrolladas por los movimientos sociales, entendiéndolas como estrategias de formación. El estudio aquí presentado es el resultado de más de quince años de investigación académica junto a movimientos sociales de Brasil y Argentina. Desde esta perspectiva, realizamos una revisión bibliográfica de la obra central de Freire, Pedagogía del Oprimido, presentada aquí en dos partes: el Complejo del Oprimido y el Circuito Dialógico, en tanto síntesis que ofrecemos de la propuesta pedagógica de Freire. Nuestro objetivo es contribuir a un conocimiento más amplio sobre estos procesos formativos, promoviendo las experiencias educativas de los movimientos sociales y difundir el pensamiento de Freire.

\section{PALABRAS CLAVE}

Paulo Freire; Pedagogía del Oprimido; movimientos sociales; Circuito Dialógico; temas generadores; invasión cultural. 


\section{INTRODUCTION}

Paulo Freire (1921-1997) is one of the most renowned Brazilian intellectuals and one of the most prominent pedagogues in the post-war world, although some political sectors currently question his appointment as patron of Brazilian education (2012), placing him at the center of an ideological dispute in his home country ${ }^{1}$. Still, his work continues to be an indispensable reference in many Universities. He also plays a major role in the socio-educational experiences developed by Latin American social movements in the 21st century, since the history of Popular Education in Brazil is interwoven with his biography (Elisalde, 2013; Torres, 2017).

This study is the result of more than fifteen years of academic investigation among social movements from Brazil and Argentina, particularly in collaboration with the Center for Human Labor Studies (Núcleo de Estudos sobre o Trabalho Humano - NESTH/UFMG) in Brazil, and the Center for Labor Studies and Research (Centro de Estudios Investigaciones Laborales - CEIL/CONCIET) in Argentina. Our research targeted different populations in a situation of social vulnerability, such as miners, slum communities (favelas), Brazilian landless peasants, and Argentinian factories managed by their workers once they were abandoned by their former owners ${ }^{2}$ (Ramalho, 2011; 2019).

During our research, we developed several socio-educational processes of community literacy and civic education, while managing income generation projects, as well as accompanying the process of occupation of abandoned lands in Brazil and factories in Argentina. In the course of these socio-educational processes, we found ourselves confronted with moments in which different emerging aspects of the group formation required an explanation. To understand what was happening, the investigation often found support in Paulo Freire's writings about the struggle between the subjectivity of the oppressed and that of the oppressor within a group in formation.

Therefore, Paulo Freire's work was often required by the researchers to answer these emerging questions, as it provided several key analytical aspects to understanding the formative processes in which we - the researchers - found ourselves immersed. By articulating the different moments experienced by us through these various socio-educational processes, we are now able to present a systematization of the so-called Paulo Freire's Method of Education - pedagogy of the oppressed.

In this work, we present a synthetic reading of the characteristic elements of pedagogy of the oppressed - also known as Paulo Freire's method of education - focusing on the pedagogical processes developed by the social movements. As a key analytical aspect, we will examine the understanding of the socio-educational experiences of social movements as strategies of formation developed so that populations, in different situations of social vulnerability, can emerge as collective subjects

1 In 2016, the Pedagogy of the oppressed was the only Brazilian book in the list of the top 100 books of English-speaking universities (G1,2016). Despite that, many media outlets question the validity of his work (Cerioni, 2019), while some political sectors want to withdraw his nomination as the patron of Brazilian education (Ortega, 2019).

2 The systematization outlined herein was first elaborated as part of the author's doctoral research, and later developed as part of his post-doctoral research. 
that react and become protagonists of their own history. From this perspective, we conducted a bibliographic review of Freire's (1987) major work, Pedagogy of the oppressed, highlighting the pedagogical devices (Figari, 2015) that characterize the anti-dialogical cultural action, and those corresponding to the dialogical pedagogy, which he advocates.

From this focal point, we can see the pedagogy of the oppressed as a dispute between the oppressor's strategies of formation and those of the oppressed ones. Although people from lower social classes have their own culture with a rich and complex worldview, the oppressive structure imposes its cultural patterns on the oppressed populations, leading them to host the oppressor within themselves as an ideal model of humanity and to adopt external cultural patterns as their own, with the adaptive purpose of integrating themselves into the oppressive structure. The pedagogy of the oppressed is an interplay between cultural invasion, which leads to the oppressed consciousness being immersed, and the investigation of the generative themes, which leads, as we will see, to the oppressed consciousness being emerged. In sum, the pedagogy of the oppressed moves between the poles of immersion and emersion of consciousnesses.

By investigating the confrontation between these poles as strategies of formation, we can outline an interpretative scheme of the mediations that are at hand to guide the meanings attributed to each situation encountered in the learning process. Some formation strategies that compose the subjective structure of a resigned behavior, which we analyze in the first part of the text and synthesize as the Complex of the Oppressed (Ramalho, 2011). In the second part of the text, we will outline a proposal of a formative strategy to confront the oppressive structure, which will be analytically synthesized as the Dialogical Circuit. In this study, we describe the pedagogy of the oppressed as the struggle between formative strategies, composed by the Complex of the Oppressed and the Dialogical Circuit, as a synthesis offered of Paulo Freire's pedagogical proposal.

The analysis of the Complex of the Oppressed and the Dialogical Circuit will show us that within each moment of the process, pedagogical mediations (Figari, 2013) are interposed to regulate communication between the participants of the educational process, adjusting the moods and guiding the attribution of meanings through each new stage of the process. If we emphasize the characteristic that synthesizes each one of these steps separately, we can then develop a pedagogical circuit for each of the two processes mentioned. Each of these two circuits will contain five pedagogical devices, considered to be key devices because they highlight the nature of the pedagogical mediations involved in each phase. This analysis provides us with comprehensive elements of the pedagogical mediations that will favor the collective appropriation of a problem situation experienced. Therefore, when considering the investigation of the generative themes as formative strategies, we will search for the pedagogical devices that may play a role in the dispute between individual resignation and the exercise of the collective organization.

Therefore, according to our analysis, we will be able to synthesize the strategies of formation in dispute, by contrasting the Complex of the Oppressed with the Dialogical Circuit. According to our perception, this analogy will highlight 
the particular content of the pedagogical mediations involved in the processes of formation mentioned. At the end of the text, we outline a proposed Analytical Model to promote these popular experiences created by the social movements and spread Paulo Freire's thinking.

\section{THE COMPLEX OF THE OPPRESSED}

\section{CULTURAL INVASION}

Paulo Freire defines cultural invasion as the founding element of the oppressed complex: "In this phenomenon, the invaders penetrate the cultural context of another group, in disrespect of the potentialities of the latter; they impose their own view of the world upon those they have invaded and inhibit their creativity by inhibiting their expression"3 (Freire, 1987, p. 86).

It is the transmission, through various means of communication and institutional forms, of specific cultural guidelines postulated as correct, to which a natural existence is attributed, as if they had a consensual acceptance, even when they are fragrantly strange to the reality of the various groups who receive them ${ }^{4}$.

This transmission of information about the oppressive culture is constant and diversified, and configures a penetration of cultural guidelines, which imputes specific values regarding what should be considered good and evil, and the criteria on what should be considered right or wrong. The perception of these social values is inculcated as if they were something static, transhistorical, and originated from external causes, beyond the will of any individual. Thus, the cultural invasion causes the overlapping of a specific worldview above any other that may exist: the worldview of the oppressor over that of the oppressed ${ }^{5}$.

Therefore, this transmission of foreign cultural guidelines must be supported by a focal view of reality, in which its constituent elements are only partially outlined. It is a way of codification of the social totality, in which the contradictions of reality are isolated in their constituent parts so that it is difficult for the learner to realize the connections between them and identify a social problem experienced by others with their own, relating them to their causes. Consequently, this focal

3 The translations into English of the original Portuguese texts used herein, from the book Pedagogy of the oppressed (Freire, 1987), were made by the author of this text. For further information, please check the bibliographical references (Freire, 2005) for a version of the complete text in English.

4 Although indigenous and African cultures are an important part of the Brazilian culture (Holanda, 1995), sociologist Florestan Fernandes (Oliveira, 2010, p. 121) identifies "[...] that the great Brazilian cultural tradition is of a closed cultural elitism, in a society in which knowledge, the book, and even the philosophy of illustration have always been cultivated".

5 This is what Santos (2010) considers as the colonization of knowledge, which leads to a process of epistemicide (the killing of one's epistemologies), while Quijano (2014) explains that these criteria of right and wrong constitute a colonial pattern of power that he synthesizes as a knowledge-power. 
mode of existence keeps the problems of the oppressed isolated, avoiding that they understand reality as a whole ${ }^{6}$.

The oppressive reality isolates its contradictions rendering it " $[\ldots]$ impossible to present the world as a problem, but rather, as something given, as something static, to which men should adjust themselves"(Freire, 1987, p. 80). By not capturing the social totality, this focal view presents the reality as something unchangeable, in which the only option is to adapt. Therefore, the anti-dialogical cultural action establishes a mythification of the world's contradictions so that it is impossible to present it as a problem. The oppressive reality is falsely seen as something fair (rich people are winners), natural (an external causality, that's the way things are), and unchanging (it has always been like that) ${ }^{7}$.

Through this manipulation, the dominant elites are conforming the invaded populations to their objectives, shaping their standards, and their ways of life (Freire, 1987, p. 83). However, these myths are seen as true because the oppressed accept the criteria imposed by the oppressor as something positive and their myths as truth.

In summary:

The cultural invasion, which is intended to conquer and preserve the oppression, always involves a focalized view of reality, a static perception of the world, and the imposition of one world view upon the other. It implies the superiority of the invader and the inferiority of those who are invaded, as well as the imposition of values by the former, who owns the latter and is afraid of losing them. (Freire, 1987, p. 91)

\section{SELF-DEPRECIATION}

A successful cultural invasion consists of the recognition, by those who are invaded, of their subordination, once their culture is positioned at a lower level, subsequently recognizing the invaders as superior.

"As a manifestation of the conquest, cultural invasion leads to the inauthenticity of those who are being invaded. Its agenda responds to the values, standards, and goals of the invaders" (Freire, 1987, p. 86).

6 "The totality of a region is pulverized into local communities, without these communities being studied as a totality in themselves, since they are partialities of another totality (an area, sub-region, etc.), which in turn are integral parts of a larger totality (the country, as a part of the continental totality)" (Freire, 1987, p. 80).

7 "[...] the myth that all persons are free to work where they wish, and if they don't like their boss, they can leave him and look for another job; [...] the myth of private property as fundamental to personal human development $[. .$.$] the myth of the indus-$ triousness of the oppressors and the laziness and dishonesty of the oppressed, as well as the myth of the natural inferiority of the latter and the superiority of the former. All these myths (and others the reader could list), the internalization of which is essential to the subjugation of the oppressed, are presented to them by well-organized propaganda and slogans, via the mass communications media. As if such alienation constituted real communication!" (Freire, 1987, p. 79). 
For the cultural invasion to succeed, it is essential that those invaded become convinced of their intrinsic inferiority. [...] if those who are invaded consider themselves inferior, they must necessarily recognize the superiority of the invaders. The values of the invaders thereby become the guideline of conduct for the invaded ones. The more intense the invasion and the more those invaded are alienated from the spirit of their own culture and from themselves, the more they want to be like the invaders: to walk like them, dress like them, talk like them. (Freire, 1987, p. 87)

The stigmatizing statements widely pronounced about the inferiority of the oppressed must convince them of their own inability, which is succeeded when they start to hear from themselves that they are inferior. However, this is considered an act of violence because it leads to the inauthenticity of the invaded ones, holding back their creativity by inhibiting its expansion.

Self-depreciation is another characteristic of the oppressed, which derives from their internalization of the opinion the oppressors hold of them. So often do they hear that they are good for nothing, $[\ldots]$ that in the end they become convinced of their own unfitness. [...] They speak of themselves as the ignorant ones and say the professor is the one who has the knowledge and to whom they should listen. The criteria of knowledge imposed upon them are the conventional ones. (Freire, 1987, p. 28)

With one's perception inhibited, the oppressor appears as being invulnerable, whether for concrete reasons, due to their power that always gives a testimony in contrast with the situation of social vulnerability (vital insecurity) in which the oppressed ones find themselves in, or whether for subjective reasons, associated with an overvaluation of the power contained in the holders of the hegemony, a form of fear as a way of social control ${ }^{8}$.

\section{CULTURAL ADHERENCE}

The cultural adherence of the oppressed consists in accepting the standards imposed by the oppressor as positive and considering such positive valuation as their own conclusion, holding the oppressive myths as true. Thus, they incorporate the cultural standards of others as if they were their own guidelines for life (Freire, 1987, p. 85).

The invaded have their ways of life shaped, internalizing what has been overdetermined by the oppressors as their own desiring conditions. Since the oppressors prescribe the purpose of the oppressed person, the oppressed person themselves lacks a purpose (Freire, 1987, p. 51). The more the majority of the population adapt themselves to the purposes prescribed to them by the dominant minorities, the more they will lack their own purposes, once the oppressors prescribe their conduct in life. "Every prescription represents the imposition of one

8 The oppressed "have a diffuse, magical belief in the invulnerability of the oppressor. In their power that always gives a testimony" (Freire, 1987, p. 28). 
individual's choice upon another [...] the behavior of the oppressed is a prescribed behavior. It follows a foreign guideline imposed to them - the guidelines of the oppressors" (Freire, 1987, p. 18).

The oppressors prescribe the conduct of the oppressed when the oppressed wants to achieve the oppressor's standard of living as their purpose, therefore incarnating (which is rarely effective) the values and conduct of the rich classes. However, the oppressed, as invaded by the oppressor's morality and desiring condition, act in a way that is contradictory to their reality, given that the acceptance of the values of the wealthy classes, as a means to achieve a desired standard of living, is not consistent with their concrete existential situation. Thus, cultural adherence leads to the inauthenticity of the invaded being, as one's conduct does not match one's reality. Moreover, in this process of adaptation to the foreign culture that they receive, the invaded populations place themselves under the threat of losing their cultural originality.

Cultural adherence, then, turns the oppressed into a being-for-the-other (Freire, 1987, p. 20); a being that exists in function of the other, because the other tells them how they should behave. In each of their activities, the oppressed work for the benefit of their oppressors: in the context of work, for example, we see that the product of their work does not belong to them, and even if they depend on it to live, they can only have a job to the extent that it is exploited for the benefit of others. The same can be argued about families and the educational system?

The oppressed dual constitution consists of the ambiguity of the culture they assimilate, turning out that one part of their selves is adhered to the oppressive culture, while the other is undeniably immersed in its palpable reality. Thus, the oppressed are divided because the condition of their own existence is established by interests that are antagonistic to their own. The maintenance of the oppressed duality is directly related to the maintenance of their adherence to the oppressive reality.

Part of the oppressed self is located in the reality to which it finds itself adhered to and the other part is located outside, surrounded by strange entities, which are regarded as responsible for the objective reality, about which nothing can be done. [...] The very concrete situation of oppression, by dualizing the self of the oppressed, making it ambiguous, emotionally unstable, and fearful of freedom, facilitates the divisive action of the dominator in the same proportion in which it hinders the unifying action indispensable to the liberating practice. (Freire, 1987, p. 100)

For the dialogical pedagogy, it will be essential to highlight that the human being, who adhered to the nature and the figure of the oppressor, is probibited from being (Freire, 1987,p.101). The pedagogy of the oppressed will try to problematize

9 "The parent-child relationship at their homes generally reflects the objective-cultural conditions of the totality in which they are surrounded. If the conditions that penetrate the home are authoritarian, rigid, and dominating, the atmosphere of oppression will be intensified. [...] This atmosphere at home extends into the school experience where the students soon discover that, (just like at home) to achieve some satisfaction, they must adapt to the precepts that have been set vertically from above. One of these precepts is not to think" (Freire, 1987, p. 87). 
this dual constitution: as they exist due to their dependence on the other, they experience a kind of death in life, as their life cannot be considered life because it is regarded as a thing - which is the target of the domination.

\section{HOSTING THE OPPRESSOR}

The oppressed host the oppressor when they assimilate the oppressor as their ideal model of humanity. The oppressor, by penetrating the oppressed, becomes housed in them, causing the oppressed to have, in the oppressor, their testimony of humanity (Freire, 1987, p. 71). By internalizing the desiring conditions of the oppressor as their own, the values of the oppressors become the guideline of the invaded, who will want to look like them, dress like them, and walk their way:

[...] there are some specific moments in which the oppressed, in their existential experience, feel an irresistible attraction towards the oppressors and their way of life. Participating in these standards of life becomes an unquestioned aspiration. In their alienation, they want, at all costs, to look like the oppressor. (Freire, 1987, p. 28)

The duality of the oppressed is composed by the ambiguity of the culture they assimilate, and that culminates in the maintenance of themselves being (self-) focused on an other-exterior. This prevents the oppressed from acquiring awareness of themselves, that is, of their particular existential condition, and also hinders their awareness of the existence of their social classes, as a perception of the totality of their situation - not all unique - and of the oppression in which they live, which is correlated to various contexts of other oppressed groups.

The oppressed focus their aspirations on achieving a standard of living found in a distant reality, making them disregard the conditions of the territory they inhabit with their peers (Ramalho, 2011). Thus, the oppressed tend to develop only individual solutions to their social problems, as they have constrained the possibility of thinking about other ways of appropriating their situation ${ }^{10}$.

Once they have adhered to the culture of the dominators, the only option that appears plausible to them is to be integrated into the oppressive structure, to seek to be a part of it or to gravitate around it. In this way, they see constant adaptation as the only feasible solution. "The structure of their thinking is conditioned by the contradiction lived in the concrete, existential situation in which they are formed" (Freire, 1987, p. 17).

As the oppressed have their testimony of humanity in the oppressor, the oppressed reproduce the oppression because they have learned nothing else. As the oppressed have in the oppressor the ideal example of humanity, their whole being develops in the interplay of these contradictions, this ambiguity. "Their ideal is to be men, but for them, to be men is to be oppressors, in the contradiction in which they have always been and whose overcoming is not clear to them. These are their model of humanity" (Freire, 1987, p. 17).

10 "Their vision of the new man is an individualistic vision. Their adherence to the oppressor does not enable them to be self-conscious as a person, nor as an oppressed class" (Freire, 1987, p. 18). 


\section{FEAR OF FREEDOM}

As the oppressed host the oppressor as their master, they start to fear their own freedom. "The oppressed, who introject the shadow of the oppressor and follow their guidelines, fear freedom, insofar as the eviction of this shadow would require them to fill the void left by the expulsion with another content - that of their autonomy" (Freire, 1987, p. 18). As the oppressed hold their example of humanity in the oppressor, they do not know what new content could replace the foreign cultural guidelines imposed upon them once it is imputed as something natural and even desirable. In their ambiguity, they fear falling into a kind of emptiness if they decide to discard the well-structured worldview imposed by the oppressors. The fear of seeing oneself as precipitating into an abyss is, then, equivalent to the fear of freedom (Freire, 1987, p. 18).

The oppressive reality functions as an immersion force of the consciousnesses, since it constitutes itself as a kind of absorption mechanism of those who are in it (Freire, 1987, p. 21). Immersed in the gear of the oppressing structure, the oppressed will fear freedom until they take the risk of facing their situation of oppression (Ramalho, 2011). Instead, they usually appeal to magic explanations or a fatalistic view (immutable powers), to which they transfer responsibility for their situation.

The emersion of their consciousness will require them to recognize their ambiguity and take the risk of facing it, recognizing the oppressive order and their inauthentic situation as hosts of this order, so that, based on criticizing the prevailing hegemony, they no longer see their reality as a closed world, but as a limit imposed externally, then, changeable.

The great problem lies in how the oppressed, who hosts the oppressor himself, can participate in the elaboration of the pedagogy of their liberation, as double beings, inauthentic as they are. Only as far as they discover that they are hosts to the oppressor, they will be able to contribute to the parturition of their liberating pedagogy. (Freire, 1987, p 17)

As the worldview of the oppressed is structured by a whole series of patterns, alien to the individual's reality, their autonomy (freedom) is only feasible if they accept the challenge of reconstructing their cognitive order of the world and take responsibility for bringing out a new structure, filled with their own content. The oppressed must develop their understanding of reality as a process, i.e., that reality is formed in the relationships the human being establishes with it. First, the perception of the world is transformed by the dichotomization between the oppressed and the oppressing consciousness. Then, the myths of the oppressive structure are expelled, preserved only as mythical spectra in the new subjective structure, filled with another content of its own, of its authenticity.

In opposition to the Complex of the Oppressed explained above, we will now address the Dialogical Circuit, as a synthesis offered of Paulo Freire's pedagogical proposal (Ramalho, 2011). The consciousness of the oppressed populations emerges through a group process developed through the pedagogical action, as a formative process that goes from the predominant cultural adherence to the formation of an 
untested-feasibility ${ }^{11}$, which emerges as a new proposal understood as viable for the group participating in the learning process.

\section{THE DIALOGICAL CIRCUIT}

\section{PROGRAMMATIC CONTENT}

In the proposed scheme, the pedagogical action begins with a dialogue over the programmatic content to be taught. The organization of the programmatic content, inside a determined area of study, is based on the approach to topics that, in the dialogue, are seen as meaningful for the participants of the process ${ }^{12}$.

In any case, the movement should start from the relationships that the participants establish with their local and immediate reality - as Paulo Freire says, from a man-world relationship, based on their here and now ${ }^{13}$. Therefore, it is not a matter of dealing with a general theme, such as unemployment in a country or inequality worldwide, but to propose a discussion based on specific structural contradictions of the concrete and present existential situation of the people. That is because longings, doubts, anxieties, and experienced desires come up when human beings discuss their tangible context, their activities, and how they are acting. The expression of which conforms to the primary material of the research on the thematic universe shared by the group.

Therefore, this pedagogical proposal implies a reflection on the world to bring out the significant themes implicit in it and, consequently, select a thematic universe that reflects the set of common aspirations of the participants. In general, the organization of the programmatic content consists of an investigation on the thematic universe of the group to elaborate a cultural synthesis regarding its world view. People's worldview reflects their existential situation and manifests itself in the various forms of action that human beings adopt or are willing to adopt. However, we must emphasize that the programmatic content research is not intended for the participants in the process themselves, but for the thought-language, which the learning group uses to refer to their experiences and the different levels of perception about the reality existing among them.

"It will be from this present, existential, concrete situation, reflecting the set of aspirations of the people, that we will be capable of organizing the programmatic content" (Freire, 1987, p. 49).

11 To designate the pedagogical mediations that we want to highlight here, we will use the terminology found in Ana M. A. Freire's (2014) notes to the English version of the book Pedagogy of hope. So, we are going to adopt the terms Perceived-Detached and Untested-Feasibility to designate two of the pedagogical mediations contained in the Dialogical Circuit. Nevertheless, we could propose, for future studies, the translation of these two terms, as Perceived-Highlighted and Original-Viable, respectively.

12 This does not mean that the educator is deprived of searching for prior information to acquire certain familiarity with the situation in which they will find themselves: "Once the investigators have determined the area in which they will work and have acquired a preliminary acquaintance with the area through secondary sources, they initiate the first stage of the investigation" (Freire, 1987, p. 59).

13 "[...] the movement begins from the man-world relationship. That is why this starting point is always in men in their here and now [...]" (Freire, 1987, p. 42). 
It is not our role to speak to the people about our own view of the world, nor to attempt to impose that view on them, but rather to dialogue with the people about their view and ours. We must be convinced that their worldview, which manifests itself in their various forms of action, reflects their situation in the world, in which they are constituted. (Freire, 1987, p. 49)

[...] the object of the investigation is not the persons themselves, as if they were anatomical pieces, but rather their thought-language with which men and women refer to reality, the levels at which they perceive that reality, and their view of the world, in which their generative-themes are found. (Freire, 1987, p. 50)

\section{THE GENERATIVE-THEMES}

The task of the dialogic educator is not to present again, from another point of view, the thematic universe captured, in the sense of disserting about some point of the thematic universe, i.e., to clarify adjacent questions to the content in a disciplinary manner; but rather to represent the thematic universe received as a problem. It is about working over the thematic universe collected in the investigation as a team and returning it as a problem to the people from whom it was received ${ }^{14}$.

Based on this thematic universe elaborated among all the stakeholders, some key themes of the debate are gradually clarified. The selection of the generative themes to be developed considers issues that share scientific knowledge and other types of knowledge - those seen more often in their potentiality of being developed as a challenge that requires an answer. An answer that has its unfolding potential in the challenging character attributed to it, and on which it feels necessary to focus its action, inside a tangible situation and in a determined context.

Insofar as the participants in the process establish correlations between the different aspects of reality in order to unfold the narrowness of the apprehended situations, they can capture the reality in its deepest implications, expanding their field of perception. Individuals broaden their conception by analyzing the partial dimensions that impact them, apprehending themes that are implicit in them or themes referred to them, and observing the interaction between the elements of reality that make up a whole.

The research of the generative-theme implies a constant act of unveiling the reality, in the sense of erecting a plan of totality through the organization of its constitutive elements. It is a question of acquiring the ability to split a theme into its fundamental cores, which include its partialities, to be able to go back to the totality, knowing it better (Freire, 1987, p. 67). By being able to move from the general to the particular (and vice versa), the individual understands how much a regional aspect can contain themes that are universal, in the sense that they belong to a broader epochal unity.

When people lack a critical understanding of their reality, apprehending it in fragments, which they do not perceive as interacting constituent elements of

14 "By working, within an interdisciplinary team, on the thematic universe collected in the investigation, the task of the dialogic educator is to return it, as a problem, not as a lecture, to the men from whom it was received" (Freire, 1987, p. 59). 
the whole, they cannot truly know that reality. To truly know it, they would have to reverse their starting point: they would need to have, first, a total vision of the context to subsequently separate and isolate its constituent elements and, through this analysis, achieve a clearer perception of the whole. (Freire, 1987, p. 55)

Generative themes can be located in concentric circles, moving from the general to the particular. The broadest epochal unit, which includes a diversified range of units and sub-units - continental, regional, national, and so forth contains themes of a universal character. (Freire, 1987, p. 54)

At this time, when the oppressed are unveiling the world of oppression, we must keep in mind that this change in the perception of the oppressive world by the oppressed places us in front of the problem of the oppressed consciousness in contrast with the oppressive consciousness; that is, of the duality of the oppressed. "And it is as dual, contradictory, divided beings that we must face them" (Freire, 1987, p. 23). The understanding of the whole moves in the direction of sedimenting the perception of the dichotomy that exists between the worldviews of the oppressors and the oppressed. That means: to gain a critical awareness of the oppression, developing their consciousnesses through the critical understanding of the dichotomy between oppressive and oppressed consciousness.

The more the participants reveal the objective reality of oppression, the more they insert themselves critically into it, as they begin to question the oppressive order. Once they unveil the world of oppression and perceive the myths that feed it, the exigency to influence the concrete situation that generates the oppression is, then, in its stage of conformation.

\section{THE LIMIT-SITUATION}

When the dialogue deepens and reaches a certain peak, when the discussion becomes tense, then, the limit-situations appear. A limit-situation takes place in the approach of topics considered as taboos, about which one should not talk about (or is better not to), because they are placed as fixed symbolic constructions in people's cognitive network. These situations, then, are seen as insurmountable issues, treated as unchangeable determinations, to which a natural character existence is attributed (it has always been like this), as well as universal acceptance (they are transmitted because they are consensually accepted $)^{15}$.

Developing a limit-situation is questioning these precepts perceived as natural and universal. By unveiling how they are constructed, they can be shown as myths that cover up reality - and the reality covered up by these myths limits the willingness to perceive and act.

15 Freire (1987,p. 54) mentions the example of an underdeveloped a country, for instance, Brazil, which is seen as something natural, like a twist of fate (a divine plan). However, this situation is not accidental if we consider it as a consequence of the structure of economic dependency. In this limit-situation, all measures taken to foster development (even if a dependent one) as the equivalent of modernization are the same, despite the fact that it will actually benefit the main capitalist countries around the world. "For all of this, it is necessary not to mistake development with modernization. Modernization, which is always induced, even if it reaches some parts of the satellite society, is basically at the benefit of the metropolitan society" (Freire, 1987, p. 92). 
"[...] the themes (of life) are covered by the limit situations, which present themselves to men as if they were overwhelming historical determinations, in the face of which they have no alternative but to adapt" (Freire, 1987, p. 53).

"In general, a dominated consciousness that has not yet perceived a limit-situation in its totality apprehends only its epiphenomenon and transfers to the latter the inhibiting force, which is the property of the limit-situation"(Freire, 1987, p. 54).

The perception of the dichotomy between the oppressor and the oppressed must highlight the contradiction within which the culture presented by the oppressor does not match the reality of the oppressed. The treatment of the limit-situation transits in the direction of expressing the ambivalence existing between the cultural agenda transmitted by the oppressors and the existential situation of the oppressed, and the existence of antagonistic principles in the comprehensive precepts that determinate what is right, what is true.

Armed with a holistic panorama over their specific context, the oppressed can then highlight the existing dichotomy between the oppressed and the oppressing consciousness so that the cultural agenda of the invading structure in the oppressed consciousness can be explicitly revealed as a mythical phenomenon - and therefore non-plausible of achievement. When one understands that reality is composed of the relationships human beings establish with it, the veil that covers it up is removed as something naturally given, since the definition of what should be equivalent to right and wrong is based on socially constructed patterns, which are antagonistic concerning the situation that the oppressed find themselves in.

Then, a situation that seemed immutable and of independent origin, by being shown in its ambivalence, is tensioned and emerges as a contradiction that can no longer persist, i.e., a situation of life in which the co-existence of antagonistic standards is shown, and which therefore requires a solution. In this sense, the tension conforms a necessary part of the pedagogical process proposed by Paulo Freire, given that, tension is placed as a conscious pedagogical mediation in handling the limit-situation, since it expresses the coexistence of antagonistic criteria - among which, then, a posture must be adopted by the participants of the process.

It is indispensable for the oppressed, in their struggle for liberation, that the concrete reality of oppression appears no more as a kind of closed world (in which their fear of freedom is generated) from which they cannot escape, but a situation that only limits them and that they can transform. Then, it is fundamental that, in recognizing the limit that the oppressive reality imposes on them, they can conceive this knowledge as the engine of their liberating action. (Freire, 1987, p. 19)

By elucidating the ambiguity contained in assimilating a culture founded on interests that are antagonistic to their own, one can allow individuals to discover themselves as hosts to the oppressor and that, as dual beings, they are not being able to be (Freire, 1987, p. 49). When they realize the impossibility of their realization in life by maintaining their connivance with the oppressing regime, the need to overcome the contradiction in which they find themselves is highlighted, as a way for them to become beings for themselves. 
Elaborating a social totality broadens the person's perception about the dichotomy that exists between the worldviews of the oppressor and the oppressed so that they can achieve a more introspective look, focused on themselves and their aspirations in life. Such dichotomy can also be translated as the opposition between being-for-themselves and being-for-others. Recognizing that conflicting interests guide their behavior, the persons begin to wonder about how to establish their own criteria and act consistently with the situation in which they find themselves in the world. Through this dialogic process, the individuals realize that: "Their solution is not to be integrated or incorporated into the structure that oppresses them, but to transform it so that they can become beings for themselves" (Freire, 1987, p. 35).

\section{PERCEIVED-DETACHED ${ }^{16}$}

The problematization of a limit-situation must highlight the perception of these impediments that we have discussed above, of what is regarded as taboo, as exemplary references of problems in the world to need to be changed: injustice, inequity. Once these taboos are understood as they are - restraints, limitations the oppressed begin to see them as obstacles to their aspirations, transforming them into perceived-detached elements. This detachment that takes place in the Dialogical Education emphasizes the problematic character of the situation the oppressed are living in, and then, instead of a limit-situation that is insurmountable, they will acquire the perception of a challenge to overcome.

"What previously existed as objectivity, but was not perceived in its deepest implications and, at times, was not even perceived, stands out (detaches itself) and takes on the character of problems, therefore, challenges" (Freire, 1987, p. 41).

If the limit-situations deal with mental and behavioral structures, which appear as fixed and eternal, now, as they are detached-and-perceived (Freire, 2014), they emerge as a reference point of a challenging context that needs to be faced. The situation initially faced as something given, seen now in its various connections and deeper implications, takes on the character of a problem to be overcome. Once we assume a situation as problematic, we also start to question ourselves about the need to solve it, about how to solve the dilemma.

In the process of investigation, when individuals problematize their conduct in the world, they recognize their own characteristics and their unique properties. The more they problematize themselves, the more they recognize themselves by identifying themselves in it. And, as they realize they are recognizing themselves in the process of problematizing themselves, a movement is erected in which the individuals engage themselves, since their resulting understanding becomes increasingly critical, as they connect their problem situation with others related to it. At this point, we can clearly see the relationship between recognition and commitment in the pedagogy of the oppressed:

16 Ana Maria Araújo Freire (2014) considers the more profound study of the transition from the limit-situation to the perceived-detached as especially meaningful, as a way to understand the construction of the untested-feasibility, which, in her view, is very little exploited in view of its importance to understand Paulo Freire's work. 
The more the students are problematized, as beings in this world and with the world, the more they will feel challenged. The more challenged, the more obliged they are to respond to the challenge. Challenged, they understand the challenge in the very action of capturing it. But precisely because they perceive the challenge as a problem in their connections with others, on a plane of totality and not as something petrified, the resulting understanding tends to become increasingly critical.

Through that, which provokes new understandings of new challenges, which emerge in the response process, more and more they will recognize themselves, as a commitment. This is how the recognition that engages is achieved. (Freire, 1987, p. 40)

The critical recognition of their situation imposes on them the need to overcome this contradictory situation, as this appears as a condition for the achievement of their aspirations. By questioning their prescribed behavior through their adherence to the cultural agenda of the oppressive structure, they gradually organize a system of dispositions to perceive and act in the search for what appears to them as a condition for being more. This means a willingness to act in the sense of influencing the oppressive structure, in the construction of one's possibilities of erecting oneself as an authentic being, a being-for-oneself.

By becoming aware of the social totality in which they are inserted, individuals until then immersed in their reality, only with the pure sensitivity of their needs, emerge from it by acquiring the reason of their needs, assigning a meaning to the achievement of their aspirations in the world. When the oppressed discover the oppressor, they begin to believe in themselves, because they recognize the shape of those aspects that conform to the hegemony, realizing that their capacity of agency over reality may be limited, but is not inexistent.

The individuals recognize themselves in the problems they develop during the investigation (which, from the generative-theme, has reached a limit-situation and then become a perceived-detached element, subsequently transubstantiated into an untested-feasibility) and start to accept their responsibility towards their situation: "[...] the problem-solving conception - that does not accept a well behaved present, as does not accept a pre-determined future - by being rooted in a dynamic present, becomes, then, revolutionary" (Freire, 1987, p. 42).

The processing of the perceived-detached consists in developing this confrontation, putting to the human beings their condition of confrontation with this reality - in which the reason of their social situation is historically given - as their own situation, i.e., as something of their own. The incorporation of the social antagonisms not as a limit (social ceiling), but as a problem to be solved, raises the notion of the existence of a border to overcome. Now, those limits appear as frontiers that separate two things: the truth of the oppressor and the autonomy of the oppressed. The reality appears, now, as this boundary situation faced as a limit to autonomy, to the realization of the person in life. Instead of an insuperable barrier, this limit is now interpreted as a border between being-for-yourself and being- 
for-the-other - enabling the reversion of the fear of freedom, which we addressed in the first part of the text.

When the oppressed no longer perceive the limit-situations as a "[...] border between being and nothingness, but as a border between being and being more [...]" (Freire, 1987, p. 51), they become increasingly critical in the activities linked to this perception. Perception in which the untested-feasibility is implicit, to be then defined, and once the possibility of change and new is defined, its realization will direct the activities of the participants of the formative process.

\section{UNTESTED-FEASIBILITY}

When the challenge posed by the formative process is perceived as something unsustainable, over which it becomes impossible not to act, the perceived-detached acquires the conditions to transform himself into the untested-feasibility. The transubstantiation of the perceived-detached into the untested-feasibility requires these detached impediments to appear as a contradiction that cannot continue to exist without any action being taken in its regard. "The tendency, then, of the educating-educators as of the educators-educating is to establish an authentic way of thinking and acting. To think of oneself and the world, simultaneously, without dichotomizing these thoughts from those actions" (Freire, 1987, p. 41).

This non-separation between word and action, which Freire refers to, is the result of the process in which the consciousness emerges once the re-codification of the social totality has been accomplished. When investigating the generative-theme, we reached a point where there seems to exist some disorganization of the social reality, as a result of the process of splitting the theme into its fundamental cores, which are its partialities, so that later on we can go back to the whole, knowing it better. The social totality, initially codified as a rigid, natural, and universal structure, is then decoded by the comprehension of its various constitutive dimensions (Freire, 1987, p. 67).

Splitting the codified totality allows for the organization of its constitutive elements so that people recognize the constitutive interaction of the various dimensions of the totality in which they are inserted. The totality is split up decoded - and, then, recoded, conforming a re-totalization — recoding — of the split-up totality. Consequently, this initial disorganization of social reality, which, in its persistence, needs to be redefined, now appears as reorganizable. This reorganization must have an attributed meaning of the crossing of a border situation, faced as a limit to autonomy, to the realization of the person. During recodification, the possibility of novelty is shaped, as an original proposition that at first seemed unfeasible.

The process has its outcome when the denial of the existence of a problem situation becomes a proposal to create something new, unprecedented until then for the group. This quest for the new "[...] implies the critical recognition of the reason of this situation, so that, through a transforming action that focuses on it, another one may be established, which enables that search for the being more" (Freire, 1987, p. 18). At first, the confrontation of the dominant culture takes place through a change in the perception of the oppressive world by the oppressed, as 
they unveil the world of oppression and commit themselves to its transformation. Secondly, the myths created in the oppressive structure are being dislodged, preserved only as mythical spectrums of reality in the new structure that is now filled with another content of its own, a genuine one.

The Dialogical Circuit highlights the nature of the pedagogy of the oppressed as a process, oriented to gradually transform the oppressive reality, which enables it to be overcome until a new human being emerges: no longer the oppressor, no longer the oppressed, but human beings who can free themselves in a process, mutually. A process of permanent liberation based on "[...] educational work, which must be carried out with the oppressed, in the process of their organization" (Freire, 1987, p. 23).

The pedagogy of the oppressed is the praxis of collective organization, in an attempt to restore the intersubjectivity between the participants in the process, making the oppressed an example for themselves in the struggle for their emancipation. The investigation of the generative-themes, which configures the Dialogical Circuit, institutes a communicational process that guides the action and reflection of the participants about their world to create a new structure in the very process of influencing it. In this sense, we can say that dialogue phenomenizes human intersubjectivity (Macedo, 2005, p. 8).

Novelty emerges among the oppressed by overcoming the oppressor-oppressed contradiction. Through the recodification of the whole, it is possible to overcome the fear of freedom. By properly addressing the oppressor-oppressed contradiction during the group process, one can fill the void left by the denial of the oppressor structure.

The Dialogical Circuit culminates in the emergence of an original but credible solution for the participants of the group, establishing a kind of triad between problematization - challenge - commitment to act (Ramalho, 2011). Concerning the individualizing myths of the oppressive worldview, the theory of dialogical action highlights its characteristics: collaboration, unity, organization, and cultural synthesis (Freire, 1987, p. 96).

\section{CONCLUSIONS}

In this study, we have examined the pedagogy of the oppressed as a dispute between the strategies of formation of the oppressor and the oppressed, grounded in the opposition between consciousness immersion/emersion. From this point of view, we described Paulo Freire's theory on the pedagogy of the oppressed in two parts: the complex of the oppressed and the dialogical circuit. First, we have specified the key components of the Complex of the Oppressed, resulting in the fear of freedom, as the conduct of resistance to the new. Next, we have shown the Dialogical Circuit as the processing of mediations that culminates in the emergence of an innovative solution, seen as viable within the group in formation - the untested-feasibility. Therefore, the Complex of the Oppressed is considered to find 
its overcoming in the Dialogical Circuit, as a synthesis offered of Paulo Freire's pedagogical proposal.

As outlined by our study, the duality of the oppressed is composed of the ambiguity of the culture they assimilate, once it is based on interests antagonistic to their own, and this forces them to target an other-exterior. As hosts to the oppressive order, the oppressed do not understand it is possible to behave differently from what they hold as their ideal, possessing no other form of conduct other than reproducing the oppression they see.

As addressed earlier, the Dialogical Circuit begins with the definition of the programmatic content to be taught. In this way, Freire's proposal embodies a methodological radicalism in respect to the starting point of the pedagogical action, considering that the programmatic content to be taught cannot be previously determined, neither by the educator nor by the curriculum.

We have also addressed the importance of world mediation in the pedagogy of the oppressed. According to Freire, world mediation is not using aspects of reality as a hook, i.e., as a teaching resource to make a subject more interesting and bring it closer to the reality of the student. The intention is to elaborate the thematic universe shared by the group, which is captured by understanding the thought-language used by the participants to express their experiences. Without it, the pedagogical action is compromised, according to the Freirian perspective. Therefore, the object of the investigation of the generative-themes is not the students themselves, but rather the thought-language that the participants of the group use to refer to their reality, to their life experiences in the world. In this sense, distinguishing the educator from the students is useless because the thought-language associated with the shared thematic universe of the participants in the process, which we want to capture, also includes the one responsible for teaching.

Based on our approach, we examined the process of group conformation that institutes the action of the dialogical pedagogy. We have also shown that, between each of the moments of the process, pedagogical mediations are interposed to regulate participants' communication, adjust the moods between conflicting or opposed opinions, and guide the formulation of the meanings assigned by the participants of the process for every new challenge that arises. By emphasizing the characteristic that synthesizes each of these stages, we were able to discern two opposing pedagogical circuits - the Complex of the Oppressed and the Dialogical Circuit. Each one is composed of five key pedagogical devices. According to our perception, based on these devices, we can highlight the particular content and the expected pedagogical mediations involved in the formation process.

Based on our analysis, we have synthesized the formation strategies in dispute, contrasting the Complex of the Oppressed with the Dialogical Circuit. We have outlined our analytical scheme based on such a parallel. Therefore, we have structured an Analytical Model for Freire's Method visualization, proposed as Chart 1.

From this point of view, we can see the pedagogy of the oppressed as a dispute between strategies, which is played out between individual (self-)resignation and the (self-)exercise of a collective organization. Its result can be either in the 
Chart 1 - Systematization of the Pedagogy of the oppressed.

\begin{tabular}{|l|c|c|}
\hline & The Complex of the Oppressed & The Dialogical Circuit \\
\hline 1. & Cultural Invasion & Programmatic Content \\
\hline 2. & Self-Depreciation & Generative-Themes \\
\hline 3. & Cultural Adherence & Limit-Situation \\
\hline 4. & Hosting the Oppressor & Perceived-Detached \\
\hline 5. & Fear of Freedom & Untested-Feasibility \\
\hline
\end{tabular}

Elaborated by the author.

form of self-discipline in view of cultural adherence or as the emergence of a (self-) didactic tool for the exercise of a group for the appropriation of a problem situation that has been experienced.

The collective appropriation of a problem situation experienced is the untest$e d$-feasibility. By carrying out a project based on the general perception of a frontier that needs to be crossed, the participants of the group can adopt an organizational attitude and see it as their horizon of plausible success. In seeking to materialize their claims, the members of the group create mechanisms of reciprocity and understand that the solution to the problem outlined is not found in external elements, but rather within the group, in its process of self-organization. Based on this approach, we can think of the pedagogy of the oppressed as a rupture process that moves away from the habitus (Bourdieu, 2007) that was, until then, hegemonic, to the extent that this circuit of mediations culminates in a new system of willingness to think and act.

When we look at the group's internal pedagogical processing as a key element of understanding, we can say that if this circuit is interrupted at some point during its mediations, the possibility of the individuals taking on the responsibility for their situation will be threatened, if the didactic tool for the exercise of the group is weakened. The group scheme may stagnate due to the dilemmas faced while the group's tasks are being carried out. For example, when someone refuses to take on a role assigned by the group, preferring to delegate it to a third party instead of consolidating an internal mechanism of self-regulation (Calloway, 2016). The duality of the oppressed always tends to manifest its ambivalent character inside the group. The persistence of an oppressed subjectivity among participants indicates that the oppressive worldview has only been partially resignified - a form of ambiguously evicting the oppressor as an ideal of life, when ways to integrate into the oppressive structure continue to be the objective, even if sometimes it does not manifest itself openly.

Then, between each stage of the process, there are different perception levels among the participants of the group about the meaning attributed to the action they are carrying out, even if they have a common goal (to solve the detached challenge). As the meanings attributed to each moment of the process may be different among 
the participants, the existence of different levels of perception about their reality may lead to different ways of visualizing a solution to the detached problem: some may resign themselves to an individual solution, while others may try to collectively confront the challenging reality.

The different degrees of assimilation that exist among the participants at each stage of this circuit can translate into a partial eviction of the hosted oppressor only, when considering the conducts of those who still carry a subjectivity based on the oppressive structure. Among the members of the group, we can observe a continuous tension between individual resignation and collective appropriation. This is the result of a complex equation between the established social normativity being ruptured and the reproduction of the previous identities, with an impact on how the group's conformation is consolidated.

The specific way in which each group experiences the investigation of the generative-themes conditions the transubstantiation of the previous identity into another self-organized one. Even when the untested-feasibility has been conformed, the appropriation of the situation experienced does not necessarily mean that the group is fully aware of its attributions in managing the problem situation. From a generic point of view, group conformation is involved in a permanent situation of a dispute between consolidation and reversibility, as the formative strategies of the oppressive structure do not cease to have an impact on them, even after the untested-feasibility has been established.

Group conformation, which is a part of the pedagogy of the oppressed, implies a permanent process, because there is always a latent risk of return, in the re-establishment of the previous condition, if the construction of the novelty situation is not permanently resumed.Thus, even after the untested-feasibility is achieved, we can say that a new learning process begins, in which, for example, the character of the achieved group conformation is at stake: its level of internal horizontality and its ways of dealing with external contradictions coming from the oppressive structure, which will always be present while being a hegemonic structure over the social totality. The dispute between formative strategies now entails determining which perception will prevail over the character that the group is to assume: a shared vision of its horizon of success to be achieved.

\section{REFERENCES}

BOURDIEU, P. El sentido práctico. Buenos Aires: Siglo XXI Editores, 2007.

CALLOWAY, C. Autorregulación de los colectivos autogestivos de trabajadores/as. Revista Idelcoop, Buenos Aires, n. 218, p. 11-30, Mar. 2016. Available at: https://www. idelcoop.org.ar/revista/218/autorregulacion-colectivos-autogestivos-trabajadoresas. Accessed on: Nov. 28, 2021.

CERIONI, C. Venerado lá fora, questionado no Brasil: o legado do educador Paulo Freire. Exame, São Paulo, May 2019. Available at: https://exame.abril.com.br/brasil/ paulo-freirevenerado-la-fora-exilado-no-brasil-a-trajetoria-do-educador-paulo-freire/. Accessed on: Feb. 1, 2020. 
ELISALDE, R. Bachilleratos populares y Autogestión educativa. Perspectivas y desafíos para la construcción de un Movimiento Pedagógico en la EDJA. In: ELISALDE, R.; DAL RI, N. M.; AMPUDIA, M.; FALERO, A. (Orgs.). Movimientos sociales, educación popular y trabajo autogestionado en el cono sur. Buenos Aires: Editorial Buenos Libros, 2013. p. 9-30.

FIGARI, C. Hegemonía empresarial y mediaciones pedagógicas en los espacios de trabajo. Sociología del Trabajo, Madrid, 2013. Available at: https://recyt.fecyt.es/index. php/sociologiatrabajo/article/view/54775. Accessed on: Nov. 28, 2021.

FIGARI, C. Corporaciones y dispositivos pedagógicos: la estrategia formadora del capital. Revista Estudios Sociológicos, México, v. 98, n. 33, p. 285-310, 2015.Available at: http://www.scielo.org.mx/pdf/es/v33n98/2448-6442-es-33-98-00285.pdf. Accessed on: Nov. 28, 2021.

FREIRE, P. Pedagogy of hope: reliving pedagogy of the oppressed. London: Bloomsbury Academic, 2014.

FREIRE, P. Pedagogia do oprimido. Rio de Janeiro: Paz e Terra, 1987.

FREIRE, P. Pedagogia do oprimido. Rio de Janeiro: Paz e Terra, 2005.

G1. Só um livro brasileiro entra no top 100 de universidades de língua inglesa. G1, 17 Feb. 2016. Available at: http://g1.globo.com/educacao/noticia/2016/02/so-um-livrobrasileiro-entra-no-top-100-de-universidades-de-lingua-inglesa.html. Accessed on: Feb. 1, 2020.

HOLANDA, S. B. Raízes do Brasil. São Paulo: Companhia das Letras, 1995.

MACEDO, D. Introduction - to the 30th anniversary ed. In: FREIRE, P. Pedagogy of the oppressed. New York: Continuum International Publishing Group, 2005. p.11-28.

OLIVEIRA, M. M. Florestan Fernandes. Recife: Editora Massangana, 2010.

ORTEGA, P. Bolsonaristas não querem Paulo Freire patrono da educação. Estado de São Paulo, São Paulo, May. 2019. Available at: https://politica.estadao.com.br/blogs/ fausto-macedo/bolsonaristas-nao-querem-paulo-freire-patrono-da-educacao/. Accessed on: Nov. 28, 2021.

QUIJANO, A. Colonialidad del poder, eurocentrismo y América Latina. In: CLÍMACO D. A. (Org.). Cuestiones y horizontes: de la dependencia histórico-estructural a la colonialidad/descolonialidad del poder. Buenos Aires: CLACSO, 2014. p. 285-327.

RAMALHO, R. R. Movimientos sociales y estrategias formativas: el caso de la Universidad de los Trabajadores de la Fábrica Autogestionada IMPA. Maurícias: Editorial Académica Española, 2019.

RAMALHO, R. Convergências pedagógicas entre Gramsci, Paulo Freire e Ferreriguardia - pesquisa sobre a escola libertaria. Revista Competência, Porto Alegre, v. 4, n. 2, p. 61-78, 2011. http://doi.org/10.24936/2177-4986.v4n2.2011.72

SANTOS, B. S. Descolonizar el saber, reiventar el poder. Montevideo: Trilce Editora, 2010. 
TORRES, A. C. Prácticas educativas en movimientos sociales de América Latina. Revista Folios, Bogotá, n. 46, p. 3-14, 2017. Available at: http://doi. org/10.17227/01234870.46folios3.14. Accessed on: Nov. 28, 2021.

ZIBECHI, R. Los movimientos sociales latinoamericanos: tendencias y desafíos. OSAL, Observatorio Social de América Latina, Buenos Aires, n. 9, p. 185-188, Jan. 2003. Available at: http://bibliotecavirtual.clacso.org.ar/ar/libros/osal/osal9/zibechi. pdf. Accessed on: Nov. 28, 2021.

\section{ABOUT THE AUTHOR}

Ramon Rodrigues Ramalho has a doctorate in Social Sciences from the Universidad de Buenos Aires (Argentina).

E-mail: ramon.rodrigues.ramalho@gmail.com

Conflicts of interest: The author declares they don't have any commercial or associative interest that represents conflict of interests in relation to the manuscript.

Funding: The study didn't receive funding.

Received on July 3, 2020

Approved on April 9, 2021 